\title{
The Changing Determinants of UK Television Acting
}

\author{
Richard Hewett
}

When considering the history of screen performance in academic studies, it is notable that leading contributors such as Charles Affron (1977), James Naremore (1988) and Andrew Klevan (2005) have - perhaps unsurprisingly - commonly utilised textual analysis as a means of unpacking either the signifiers and signified of selected scenes, or the particular styles of individual actors. Comparatively few, however, have chosen to focus on the contextualising background factors which combine to produce the performance ultimately seen on the screen, Roberta Pearson's Eloquent Gestures: The Transformation of Performance Style in the Griffith Biograph Films (1992) and Cynthia Baron and Sharon Marie Carnickie's Reframing Screen Performance (2008) providing notable exceptions.

While the majority of the above works focus on Hollywood 'star' performers, comparatively little work has been conducted with regard to their small-screen equivalents, and what has been written continues this primarily text-based approach. The fleeting attention paid to performance style in major works on British television history by John Caughie (2000) and Lez Cooke (2003) generally fails to consider the extent to which this was affected by production practice and historical context, changes in which have been so varied and significant over the intervening decades that some form of examination is surely now long overdue. Otherwise, any attempt at analysing the small screen acting of yesteryear risks being distorted by the passage of time, Caughie's reading of performance in Rudolph Cartier's Nineteen Eighty-Four (BBC, 1954) being notably coloured by condemnatory phrases such as 'stagey' and 'stilted' (Caughie 2000, 49). In this way Caughie falls into the analytical trap 
first highlighted by Roberta Pearson: 'While we cannot expect the average viewer... to respond in the same manner as the original audience, we can expect a film critic or scholar not to use the aesthetic standards of his or her own time and culture in judging an artefact from another' (Pearson 1990, 2). Any purely 'immanent' reading of acting in a historical text, I would argue, complicates a meaningful understanding of the performance given by failing to consider the various factors that helped shape it; examining the 'what', without considering the 'how' or the 'why'. To modern eyes the performing style of Peter Cushing et al in Nineteen Eighty-Four may well seem 'stilted', but such a description is clearly inadequate when assessing a production that, at the time of its initial broadcast, created shockwaves across the country. If we wish to understand how and why television acting has since altered to such an extent that a once-powerful performance can now be dismissed as a somewhat embarrassing relic of yesteryear, it is necessary to unpack the various conditioning factors that have changed in the interim: in other words, the determinants of television acting.

While a comprehensive overview of changes in UK television acting ${ }^{1}$ would be impossible to accommodate within a single article, this piece is intended to briefly examine its chief influences, and how they have altered since the era of live, multi-camera studio drama. The principal factors to be examined are: the time period allocated to produce a television drama, and the ways in which that time is utilised; the production process and technology employed; the role of the television director; and actor experience and training. Applying a strict system of prioritisation to these various factors would be problematic, as the determinants listed have intersected with and influenced each other at different moments and to varying extents - throughout the time period featured. For the purposes of clarity, however, I have opted to examine each factor separately, in order to provide as succinct an 
account as possible of how the primary influences on UK television acting have altered since the era of studio drama.

\section{Time}

The amount of time allocated to a television drama production is historically one of the most significant determinants of acting, the small screen's rapid turnaround setting it apart from both theatre ${ }^{2}$ and film. Yet though the fortnight that would typically be scheduled to film a one-hour television drama today is little different from the time allocated to a studio drama sixty years ago, the uses to which that time is put are markedly different in the modern era.

The pressures of preparing a performance in an extremely short period very much characterise the modern television actor's experience, with little or no time allowed for rehearsal prior to filming. In the days of studio drama, however, full cast rehearsal was an integral part of the production. Its duration would vary in length depending on the scale of the programme being made; four to five days were typical for a twenty-five-minute or half-hour slot, while ten days would be allocated to, for example, a one-hour play. Productions perceived to be more demanding, such as Shakespearean adaptations, might well be granted lengthier rehearsal times. ${ }^{3}$ Although at ITV rehearsal spaces were usually included in the same block as the studios, ${ }^{4}$ the BBC would typically rent an 'outside' rehearsal room, such as a scout hut or church hall, until the opening in 1970 of its purpose-built 'Television Rehearsal Rooms'. Based in North Acton, this seven-story block was comprised of eighteen rehearsal rooms over six floors, in addition to green rooms, production offices and a canteen. The rehearsal period was the only time the cast would have the opportunity to work closely with the director, who on studio days would be separate from them in the gallery above. The first day of rehearsals would typically begin with a cast read-through of the scripts, during which 
any cuts or amendments to lines would be agreed with the director, producer and script editor. The remaining days would then be dedicated to learning lines and 'blocking' moves with the director; coloured tape would be laid out on the rehearsal room floor to represent the sets that would be present in the studio on the day of transmission, and only rudimentary props would be used. Recording days saw the cast move into the studio for the first time; two technical run-throughs would take place prior to evening performance (in the days of live television) or recording (when videotape began to become the norm in the 1960s).

Time remains at a premium in modern British television drama; a factor which relates directly to budget, as indeed it always has done. Yet while, in the days of studio television, a greater part of the timetable was given over to rehearsal and preparation, in today's environment the emphasis has switched to the filming itself. The amount of preparation time allowed for a 60-minute episodic drama is dependent on its place in the schedule, each episode being allocated an average of two weeks' shooting as one half of a production 'block'. However, additional preparation time is allowed prior to the first block of any new series, as Howard Burch, an executive producer at Kudos Productions, explains when discussing the series Ashes to Ashes (BBC, 2008-10): 'You'd start off with the lead director, ${ }^{5}$ and then he would be given that first week of rehearsals. And in our case I think he probably used three out of the five days for rehearsals, and the rehearsal days weren't necessarily that long; you know, they'd probably start at ten, and finish certainly by four. ${ }^{6}$ The fact that so little of the first week is allotted to rehearsal is, according to Burch, due to the remainder being taken up with costume fittings, make-up tests and even last-minute location scouting and script changes. These few days represent the director's only opportunity to 'get the tone right, to get the chemistry between the actors right, to explore scenes that could be problematic, that might need re-writing, just so you've got that useful window to be able to 
sort stuff out if there are going to be any problems further down the line.' Although certain incoming directors still insist on some rehearsal time with their cast, these are in the minority. Other than the initial cast table-read of the script, which non-regulars do not always attend, actors are unlikely to have met their fellow performers before the day of filming, and on soap operas and continuing dramas such as Casualty (BBC, 1986- ) even this cursory preparation is not provided. Rather than presenting finely-tuned, prepared performances, actors today are often allowed only the briefest of run-throughs. These differences in temporal approach are amply illustrated by the reflections of two television directors, working more than fifty years apart:

Creative and interpretive work demands concentration... The effort is apparent when experienced actors are watched in rehearsal. Often the labour is a contradiction of the effortlessness that is eventually shown to the audience in performance. Indeed, at times, the rehearsal process may seem to be by far the most interesting part of the work. (Barry 1992, 42)

Prior to the shooting period you don't get to meet the actors to rehearse anything... Those few minutes before a take, that's all the time we have to quickly discover the moments we want to get out of the scene, work it through and let the crew see where we're at. Then, if we're lucky... the director and actors will get maybe ten or maybe 15 minutes to hone it down and cover any other points. (Harper 207, 46)

The first quotation, taken from the memoirs of the BBC's original Head of Television Drama, Michael Barry, ${ }^{7}$ describes the rigorous rehearsal template that survived, in one form or another, even several decades after live transmission had ceased and videotape pre- 
recording had become the norm. ${ }^{8}$ Director Graeme Harper's latter-day production diary, however, illustrates the rapidity with which television performances were evolved in the mid2000s, by which time the rehearsal process had been condensed to little more than a brief discussion before filming commenced.

From these examples it can be seen that, while the amount of time allocated to television drama is little different in 2013 to what it was in 1953, the ways in which that time is utilised have changed beyond recognition, creating an entirely new set of pressures on actors and directors alike. The only temporal advantage available today is that open to actors working on long-running series such as soaps, which, while depriving them of the luxury of a full table read, at least allows regular cast members more time to inhabit their characters than would be available in a finite serial or single drama. This arguably gives performers the time to collaborate with scriptwriters and directors familiar with their working methods, enabling leads in long-running series to 'own' their characters in a way that guest incoming actors or those starring in shorter series cannot. In the UK the turnaround on such long-running series remains a punishing one, however, and the focus clearly remains on the performance provided for the camera rather than the prior preparation that would have been the norm four decades ago. This reduction in preparation time is a direct result of the shift from multicamera studio to single camera location production, the other implications of which will now be discussed.

\section{Production Process and Technology}

The manner in which television performances are produced has changed almost beyond recognition since the days of live drama, which lasted from British television's inception in 1936 until the gradual adoption of videotape pre-recording in the 1960s. The rehearsal 
room/studio template established by the $\mathrm{BBC}$ at this time continued to predominate well into the 1980 s, but by the following decade single camera location work, of the type closer to that traditionally employed for cinema, had become the production model of choice for television drama, multi-camera studio recording being limited to sitcom and some soaps. In

performance terms, this change in modus operandi represents a shift from carefully prepared performances given once (or perhaps twice) in continuity or even in their entirety, to a situation in which re-takes are the norm and scenes - or even segments from scenes - can be shot out of story order, on different days, or perhaps even in separate weeks or months.

To gain some understanding of the impact such changes have had on performance, it is necessary to briefly unpack the multi- and single camera systems in more detail. The multicamera process originally evolved in order to meet the needs of the studio, British television drama's primary site for the first four or five decades of its existence. Once the alreadyrehearsed production transferred to the studio on the day of transmission, technical rehearsals would take place for the benefit of the camera, sound and lighting crews prior to the evening broadcast, during which the director would be cutting between as many as five television cameras 'live', in real time. This meant that it was essential for actors to hit their marks in order to remain in shot and in focus, particularly in the days of live television when the early Emitron cameras were difficult to manoeuvre and could only accommodate one lens at a time (Barry 1992, 22).

Due to the impossibility of breaks between scenes, actors would also have to position themselves in real time on sets that were located in different parts of the studio - a situation that, as already mentioned, changed little even when live broadcasts ceased to be the norm. Wednesday Play (BBC, 1964-70) producer Tony Garnett began his career as an actor in the live era, and recalls with little fondness the exigencies of multi-camera studio production: 
I remember being in a play at the Television Centre - this was live - and I was playing a boy who had a number of girlfriends. And I would be sitting in a scene with a young woman, and we would have a two-hander. So there would be a camera on her - there - and a camera on me - there. And it was written in such a way that hers was the last speech; and as soon as she started her last speech, an $\mathrm{AFM}^{9}$ would come and just tap my leg, and I would just quietly move away, and she would have her eye-line and go on speaking as though I was still there, and I would run across the studio floor, changing my clothes as I went. And before I got there that scene was over, and another scene had started with another young woman, looking straight ahead of her, and I had to sit in, pick up a drink, and be ready with my line when she'd finished that. That was the kind of nonsense that you were put in for, even after they were able to record. ${ }^{10}$

Although telerecording of live drama had begun in 1947, pre-recording of entire episodes only became possible with the introduction of Quad videotape in 1958. However, tape was initially costly and difficult to edit. In addition, the BBC's agreement with actors' union Equity stated that videotape recording time had to be limited to a maximum of three times the length of the broadcast performance (McNaughton 2014, 9), meaning that performances were still given 'as live': broken up into as few uninterrupted takes as possible, and recorded in the evening after a day of technical rehearsals.

Dismissing the pressures of continuous recording as 'utterly ridiculous', Tony Garnett claims that the decision to continue the procedure of evening performance, even after prerecording replaced live transmission, was taken in order 'to save on cutting the tape, to save on time... but of course they couldn't say that, so they elevated it into an aesthetic. And the 
aesthetic was from the theatre, which was: "the performances are better if there's continuity"',

By 1972 the situation with Equity had been resolved (McNaughton 2014, 16-18), leading to the advent of 'rehearse/record'. This meant that studio drama could, for the first time, be recorded out of sequence and edited together in post-production, with recording taking place throughout the studio day on the specific sets available, rather than being crammed into one frenetic evening session in continuity. However, this process still differed from film in that scenes were being played in their entirety, and not in mini-segments repeatedly filmed from different angles. The multi-camera recording of entire scenes meant that actors could more easily remain 'in the moment', paying less attention, for example, to maintaining the continuity of actions performed for repeated takes, which even in the era of rehearse/record were still limited due to time constraints.

The use of single camera film for television drama was comparatively minimal for the first few decades of its existence. Although pre-filmed inserts were used even in the 1930s (Jacobs 2000, 131), these usually took place before the cast had begun rehearsals, meaning that actors and directors were forced to adhere to performance choices made on location, before any real character discussion had taken place. Although the BBC remained resolutely invested in studio production following the opening in 1960 of its Television Centre base, independent company ITC began to expand its single camera film output with a view to overseas sales - particularly to the US, whose NTSC videotape system was incompatible with Britain's PAL. In the 1970s, the BBC expanded its film production on singles strands such as Play for Today (BBC, 1970-84), but over at ITV Thames Television's Euston Films was pointing the way forward with popular, all-film series such as The Sweeney (ITV, 1974-77) and Minder (ITV, 1979-93). There were indications of a move away from studio production 
at the Corporation via increased use Outside Broadcast videotape cameras for location work on programmes such as Survivors (BBC, 1975-77), allowing actors to react and respond to 'real' environments (Hewett 2013, 321-39), but by the 1980s increasing costs meant that videotape production had become little cheaper than film. ${ }^{11}$ The advent of the 1990 Broadcasting Act, followed by the introduction in 1993 of Producer Choice, ${ }^{12}$ meant that, sitcom and soap aside, in the 1990s studio multi-camera production gave way to single camera location work for the majority of television drama, independent producers having no investment in studio plant equivalent to the BBC's monolithic Television Centre.

The repeated-take nature of single camera recording means that performances can be pieced together in post-production, mediated by the employment of editing, sound effects and music. While it might be thought that the possibility of additional takes provides the actor with more flexibility, enabling them to 'try out' different performance ideas and arguably leading to greater spontaneity, the majority of these takes in fact take the form of 'coverage' from different angles, in which the same moves and intonation need to be precisely replicated for the sake of editing continuity. It could be argued that each of the systems examined here militate in their own way against spontaneity of performance, multi-camera through the need for rigorous preparation - the learning of lines and movements which cannot be deviated from once transmission or recording begins - and single camera via the necessity for continuity of actions which must be repeated and replicated for takes from various angles and framings.

There are other key differences between modern production and the studio era. Whereas studio productions were rehearsed and performed in 'continuity' (i.e. in story order), at least until the advent of rehearse/record, actors today could be filming scenes - or even segments from scenes, such as close-ups shots - on different days, maybe even weeks apart. 
The performer must maintain constant awareness of the point their character has reached in the narrative; how their circumstances have altered, and what their objectives are at this point in the story. Robert Barton describes how some actors cope with the problem of out-ofsequence recording:

Wise film actors often prepare cards for every scene ... so the actors can see the way the story should unfold. The card includes... conditioning forces, where you've just been, what you've been doing, where you're going, what you will be doing at the end of the scene, your objective, who will be in the scene with you. Actors can grab the card and take it to the set with them so they have a sense of context. (Barton 2009, 208)

Director Jamie Payne cites experienced television star David Morrissey's approach as one example of the lengths actors will go to in order to prepare for out-of-sequence filming:

Knowing that we're shooting out of continuity, knowing that he may get contradictory notes from a director - hopefully not - he does a thing where, per scene, he's got a notebook, and on one side he's got the scene, on the other side he's got all his thoughts related to that scene, and that's in response to what's just happened, where he's been. So if you say to David: 'We're shooting scene seventy-six from episode two,' he goes to his own, 'This is what I think's going on. ${ }^{13}$

Another factor to affect modern actors is the late arrival of scripts, which are often not ready until as late as the week before shooting commences. ${ }^{14}$ Whereas on a multi-camera production the script would have been effectively set in stone after the first day of rehearsal, 
today the read-through version can differ significantly from that used for filming. Lastminute re-writes are signified by differently-coloured pages of script, as director Andrew Gunn relates: 'An actor can come in, having rehearsed the scene, and be handed a blue page, you know, with a sometimes complete re-write. So you can imagine this; as an actor you've done your prep and you're suddenly handed ... these pages ... You have to adapt very quickly. ${ }^{15}$ Again, such a situation might, as Robert Barton points out, result in a more spontaneous performance: 'The film actor may have a newly memorized, newly revised script never spoken out loud in front of anyone before the moment the cameras run. It may be fresh but raw' (Barton 2009, 208). According to Jamie Payne, however, the revelation of new character information in re-written scripts can also cause actors to regret performance choices already made and recorded on film: 'Actors are given scenes, and they go: "Oh my God! If I knew [sic] that that was going to happen ... I'd have played that completely differently".'

The perceived 'spontaneity' of any television performance is also, however, dependant on the personal approaches and techniques of the actors involved, for therein lies the actor's art. Key to the formation of a personal performance style are the training received and experience possessed by the actor, the changing nature of which over the last six decades will now be examined.

\section{Training and Experience}

The ways in which any actor responds to the demands of acting for television will of course vary depending on personal style, but this will be shaped both by the training they have received and the quantity and type of experience they already possess in the medium. It was many years before British drama schools, with their traditional focus on stage skills, effectively responded to the challenges of television, screen acting courses only having come 
to prominence over the last ten to fifteen years. In addition, the theories of Russian drama theoretician Constantin Stanislavski, popularly known in their abstracted form as the 'Method' in the US from the 1930s and subsequently acclaimed for their suitability to screen work, took far longer to permeate British academies, only becoming part of the RADA prospectus in 1988 (RADA 1988, 4). Whereas actors working in television in the studio era were most likely to have begun their careers in the theatre, forcing them to adapt their performance style to the small screen, today it is television where most actors gain their first professional experience, theatre having become something to which young performers now aspire rather than providing their primary site of operation. Many television practitioners now regard the continuing episodic serial, which provides a point of entry for so many television actors, as the modern equivalent of the repertory theatre, whose decline in the 1960s was due largely to the expanding influence of the small screen.

Formalised actor training in England only began in 1904, with the founding of the Academy of Dramatic Art, or ADA (RADA from the granting of its Royal Charter in 1920); this was joined in 1906 by the Central School of Speech and Drama. Subsequent schools included the Webber Douglas Academy in 1926, LAMDA in 1938 and the Bristol Old Vic Theatre School in 1946, all of which shared an emphasis on voice and movement. This focus on theatre skills was not, however, always necessary or useful for television work, as the late Roger Lloyd Pack, who attended RADA between 1963 and 1965, described: 'We had a lot of voice classes, about speaking Received English, Received Pronunciation ... and how to do a Restoration bow - which I became pretty good at, and I've never used ever in my career.' ${ }^{\text {16 }}$

Although RADA introduced Television Technique in 1959 (RADA 1959, 7), this was limited to a few days' input in the final term, and largely fell by the wayside in the 1970s due to the cost of hiring studio space (Sanderson 1984, 281-2). Even schools such as the Glasgow 
College of Dramatic Art, ${ }^{17}$ the first academy to incorporate a television studio into its facilities, only offered limited screen input. ${ }^{18}$ In 2002, the National Council for Drama Training found that 'drama school graduates seem unanimous in their view that their first television jobs were terrifying because they knew so little of how the process works, of who was in the crew, of what was expected of them' (NCDT 2002, 9), while a 2003 Film Council report rated the ability to deal with camera auditions as prime among the notable lacks for emerging actors (Film Council/Skillset 2002, 81). However, in recent years more appropriate camera training has begun to be provided, and directors such as Colin Teague have noted a greater facility for screen work in modern drama graduates, compared to when he began his career in the 1990s:

Their confidence and their ability now - what they get trained on - is very different ... Back then there was no such thing as doing any work to camera, or even preparing for auditions, you know. Now that's pretty much there from day one; you're working with the camera, you're looking back on yourselves, you're preparing yourselves for these meetings and how you are in the room. I mean, it's amazing. 19

Former LAMDA Principal Peter James claims that 'all drama courses worth talking about now have a strand of screen acting $;{ }^{20}$ in addition to making their own films, students are also seconded to working studios and sets to help familiarise them with the technological environment. However, it is notable that such opportunities have only become available in the last decade; a comparatively recent development given the eight decades that television has been providing employment for actors. 
However, this lack of specific screen work in Britain has in many ways been compensated for by the gradual permeation of Stanislavski theory in drama schools. One of the twentieth century's most important drama theorists, Stanislavski's relevance to screen acting has been highlighted by numerous commentators, including Vsevolod Pudovkin (1953, 115-118, 147-148), Richard A. Blum (1984) and Sharon Marie Carnicke (1984, 75-87; 2004, 42-70; 2006, 21-30). Whereas in America such Stanislavskian concepts as emotion memory were seized upon and transformed into the Method as early as 1931 by Lee Strasberg, Sanford Meisner and Stella Adler at the Group Theatre, the Russian's work was initially viewed with suspicion in the UK. A 1946 article by Michael Redgrave outlined his colleagues' reactions to the Stanislavski acting manual An Actor Prepares (1934): 'Quite a few have, I know, read it and have found it immensely stimulating. Other actors have read it, or partly read it, and find it fairly frustrating. Some others again say that they have read it when what they mean is that they have always meant to read it' (Redgrave 1970, 404). Although An Actor Prepares was being taught at the Bristol Old Vic Theatre School in the 1950s, ${ }^{21}$ and from the early 1960s the Drama Centre London and East 15 began offering 'pure' versions of the Russian's theories, at the major academies Stanislavski became part of the syllabus only very gradually, and often more by stealth than design. Louise Jameson, who attended RADA between 1969 and 1971, recalls that 'the actual name Stanislavski was rarely used ... People were just picking up the language without really aligning it to Stanislavski. ${ }^{22}$ However, much of the work done at the Academy was clearly based on the Russian's theories: 'We did a lot of work on objectives and obstacles, which is the absolute foundation stone, I think, for any Stanislavski work.'

Today, Stanislavski forms a significant part of the syllabus at most major academies, his work typically being placed in context alongside the teachings of other drama theorists 
such as Bertolt Brecht, Jerzy Grotowski and Antonin Artaud. While theatre skills such as fencing and voice work are still taught, students receive a more balanced and catholic grounding for their future acting careers - which are more likely than ever before to begin in television. A 2002 report instigated by the National Council for Drama Training concluded that 'it is in television that today's graduates are most likely to get their first professional acting jobs (NCDT 2002, 7), while a 2005 Performing Arts Industry Report by actors' union Equity showed that in February of that year 18 per cent were working in television and 7 per cent in film, as opposed to 10 per cent in various types of theatre (Equity/Skillset 2005). The situation today would seem to be the reverse of sixty years ago, when television was still looked down upon and resented by many actors (Sanderson 1984, 280). At this time, theatre was the profession of choice, and it was here that most actors were likely to gain their initial grounding, typically starting in a repertory or touring company before transferring to the West End. An indication of the extent to which television work was accommodated around theatre commitments is the fact that, until 1948, repeat performances of Sunday evening plays were usually scheduled Tuesday afternoons, when actors had no clash with stage matinees (Jacobs 2000, 84). The diminution of repertory in the 1960s, followed by the decline of the British film industry from the 1970s, meant that television gradually became the primary field of employment for actors. Indeed, many already found it more convenient than long runs in the theatre, as Roger Lloyd Pack related: 'Although it's intense and hard filming TV work, you haven't got that stress of the live performance ... I prefer the hours of filming, in a way, than working in the evenings.' Trevor Rawlins has pointed out that 'in many cases professional [British] actors today rarely, if ever, work in the theatre' (Rawlins 2010, 30, and in a 2010 feature on up-and-coming British actors, Gerard Gilbert stated that 'theatre - the West End, at least - is something to be done once you've arrived' (Gilbert 
2010, 13). While those with higher screen ambitions might seek to relocate to Hollywood, it is in soap and continuing drama that most will gain their first grounding, as director Jamie Payne observes:

What you have is generations of actors now that are often being trained through the soaps, or the soap kind of schedule dramas, where they are doing versions of themselves. And they're doing versions of themselves with lots of dialogue to learn, on a ridiculous schedule. I mean, soaps do twenty pages plus a day; [on prime time drama] we do ... eight pages on a really, really tough day.'

Such a remark once again highlights the time-pressured schedules of modern television drama - a fact that has had a significant impact on the actor's working relationship with his/her director, the changing nature of which forms the last of our key determinants.

\section{Direction}

As seen earlier, directors in the studio era would work closely with actors in the rehearsal rooms, only to be separated from them on studio days, seated in a gallery above and relaying instructions via a floor manager. Although certain directors began to come down 'onto the floor' in the 1970 s, this was a very different mode of working from film, where the director could always be close at hand, literally talking the actor through each moment of their performance, if necessary. While modern television drama schedules have dispensed almost entirely with the rehearsal process, they lack the equivalent amount of time allocated for cinematic film shoots, meaning that a director's contact with their cast - and consequently their opportunity to discuss performance choices and characterisation - can be extremely limited. In addition, the power wielded by modern directors has diminished significantly when compared with the studio era. The choice of actors, once a simple matter of directorial 
preference, has now become a committee activity, to be discussed with the casting director and ratified by executive producers who ultimately have the final say in many of the key creative decisions to be made.

Whereas in the rehearsal-intensive days of studio production the cast would have had the opportunity to work out and agree the nuances of their performance jointly with the director, the onus is now on the actor to prepare their characterisation prior to arriving on set, as seasoned television actor Roger Lloyd Pack described:

It's not satisfactory. It means you have to sort of work on a character on your own, and - I've got used to it now - you can tell from the script what sort of character he is. And you sort of know what they want, really, generally speaking, although within what you do [the director] might say: 'A bit less' or

'A bit more.' You will get some notes on what you're doing, but you have to come with a character already prepared ... There's no time for any questions about: 'What do you think my character would do in this situation?'

Given the absence today of rehearsal, certain directors make the effort to meet or at least contact their actors before filming to establish some kind of prior relationship, as related by Andrew Gunn: 'When I did Life on Mars (BBC, 2006-07), you know, [lead actors] John Simm and Phil Glenister were very, very busy. But I'd managed to talk them into meeting me for dinner and a few drinks, and it was just good to have that time, a couple of hours or so, just chatting, really.' Other directors attempt to meet key cast members during rare moments of downtime during the shooting schedule, as Jamie Payne describes: 'On The Hour (BBC, 2011- ) I had to arrange time to meet Romola [Garai], Ben Whishaw, and Dominic [West] 
during their shooting day when they weren't needed. Which isn't ideal for them and it isn't ideal for me, because they're obviously looking at scenes ahead.'

With prior rehearsal now virtually non-existent, television directors are forced to provide notes 'on the spot', after watching a brief run-through of the scene to be filmed, as Payne describes:

What it means is you don't really get to challenge an actor's instinct until you're actually doing it. ... We have a lot to do, the schedules are very, very tight, as you know; I'll send the entire crew out of the room, and I'll stand on set, and ... we'll read the scene itself, and we'll block it through. And in that blocking there are questions, and you know; we test things. But the maximum time we'll have for that will be about ten, fifteen minutes.

Such a process represents a drastic compression of the discussions that would have taken place in the days and weeks that preceded studio days in the multi-camera era. Payne stresses that even this much input is very much the domain of the prime-time drama; continuing series and soaps allow the director even less contact time, in which case responsibility for performance choices automatically devolves to the actor alone:

Occasionally you'll find a scene where you haven't had a chance to talk about it, so by default the actor will understandably defer to their own position, because they have to. They're the ones on screen; if they haven't quite processed a note, or they don't quite understand it, or you as a director haven't made it clear, they have to protect themselves. On The Hour, which is the high end ... the schedule will allow you to get in between takes and give some notes. And that is speedy, and it's completely dependent on your relationship 
with that actor. Each actor needs a different relationship. Now, we're lucky that still within prime time drama the process allows that; in a soap it doesn't.

Whereas performance choices and script changes could be made during the rehearsal period in the studio era, today any significant changes must be agreed on the day of the shoot. Should the actor or director wish to make any significant deviation from the scripted action, permission must be sought from the powers above, as veteran television actor Patrick Malahide relates: 'What happens now is, there's so many suits; there's the executive producer who has to be rung up, and everybody's on their BlackBerrys. It's not a chain of command; it's a chain of indecision. And it goes all the way back up this so-called creative process, and actually prevents creative decisions being made on the floor. ${ }^{23}$

Directors today are also more constrained in terms of the casting choices they can make. While it has always been the case that incoming directors on a long-running series are forced to work with the lead actors already in place - who might well have very firm ideas on how their characters should be played - in the past, directors at the BBC at least ${ }^{24}$ were allowed to employ whomever they wished, in consultation with their producer. Today, time constraints and the afore-mentioned overall control exercised by executives mean that the director is reliant on the suggestions of the casting director, and that any selection made will be subject to veto from above. This reduction of the director's control is reflected in actor Kevin McNally's recollection of a conversation with his former I, Claudius (BBC, 1976) director Herbert Wise, after the latter worked on an episode of Inspector Morse (ITV, 19872000):

He said the big difference is that he gets hired as a director on Morse, there's a very powerful leading actor ... He's not allowed to cast because the network 
casts, and he's not allowed to budget because people are already on the show. He said when he did I, Claudius he was handed ten scripts and a million pounds and told to get on with it, and he cast whoever he wanted. So there was a lot more freedom for directors to make bold choices, and they had that pool of very experienced theatre actors to work with. Now there's much more constraints on the profile of the people they work with. ${ }^{25}$

Clearly, both the extent to which a director can work with their actors on performance choices and the power they have to shape a production via casting and script changes have significantly diminished since the days of multi-camera studio; yet another example of the changing factors that combine to shape the performance style of television actors.

\section{Conclusion}

The circumstances under which television actors operate have changed almost beyond recognition since the era of multi-camera studio, whose production patterns altered little between the live era and the introduction of videotape pre-recording, and the modern-day single camera location environment. 'Outside' rehearsal and the 'in continuity' performance of a rigorously-prepared text have been replaced by on-the-spot blocking, out-of-sequence recording, last-minute re-writes and multiple takes. While television's rapid turnaround has always distinguished it from both theatre and film, pressurised filming schedules mean that actors' opportunity to work closely with their directors on characterisation and performance are becoming ever more limited. These changes to the production template have been mirrored by broader developments in the training and culture of the acting world, the fact that the medium now provides the lion's share of employment for performers in the UK having at last resulted in an increased focus on screen skills at drama schools. 
Given such major developments, it is perhaps unsurprising if television drama performances of yesteryear increasingly resemble the relics of a bygone age. However, rather than representing easy targets for dismissal and derision via pejorative immanent readings, it could be argued that such historical pieces represent a valuable opportunity; as time capsules of their particular production eras, they offer the means to a far richer understanding both of the television of their time, and the wider world such texts represented. To fully illustrate the influence of the factors outlined here it would of course be necessary to analyse in detail some of the texts which resulted from their confluence - an exercise which falls beyond the scope of this article. However, it is to be hoped that, by demonstrating the relevance of the various determinants discussed, this article might encourage future scholars of television performance to go beyond the images preserved on film or videotape, and consider as well the ever-changing contributing factors whose coalescence helped shape them.

\section{Acknowledgements}

I would like to thank Professor Roberta Pearson of the University of Nottingham, with whom the keynote address which provided the starting point for this article was initially prepared. 


\section{References}

Affron, Charles. 1977. Star Acting: Gish, Garbo, Davies, New York: Dutton.

Alvarado, Manuel and Edward Buscombe. 1978. Hazell: The Making Of A TV Series, London: BFI.

Barry, Michael. 1992. From The Palace To The Grove, London: Royal Television Society.

Barton, Robert. 2009. Acting Onstage And Off, 5th edition, Belmont, California:

Wadsworth/Thomas.

Blum, Richard A. 1984. American Film Acting: The Stanislavski Heritage, Ann Arbor, Michigan: UMI.

Caughie, John. 2000. Television Drama: Realism, Modernism, And British Culture, Oxford: Oxford University Press.

Carnicke, Sharon Marie. 1984. 'Lee Strasberg's Paradox Of The Actor', in Lovell, Alan and Peter Kramer, eds. Screen Acting, London: Routledge, 75-87.

Carnicke, Sharon Marie. 2004. 'Screen Performance And Directors' Visions', in Baron, Cynthia, Diane Carson, and Frank P Tomasulo, eds. More Than A Method: Trends And Traditions In Contemporary Film Performance, Detroit: Wayne State University Press, 4270.

Carnicke, Sharon Marie. 2006. 'The Material Poetry Of Acting: “Objects Of Attention”, Performance Style, And Gender In The Shining And Eyes Wide Shut', Journal Of Film And Video (58:1), 21-30.

Cooke, Lez. 2003. British Television Drama: A History, London: BFI. 
Equity/Skillset, 'Working Patterns And Career Development', Performing Arts Industry Report 2005 [online], Available: http://www.skillset.org/uploads/pdf/asset_7203.pdf?1, accessed 13 July 2012.

Film Council/Skillset. 2003. Developing UK Film Talent: A Comprehensive Skills Survey Of The UK Film Industry, 81 [online], Available:

http://www.creativeskillset.org/uploads/pdf/asset_347.pdf, accessed 13 July 2012.

Harper, Graeme. 2007. Calling The Shots: Directing The New Series of Doctor Who, London: Reynolds \& Hearn.

Gilbert, Gerard. 2010. 'Right On Cue', The Independent On Sunday, 7 November, 10-18.

Hewett, Richard. 2013. 'Acting In The New World: Studio And Location Realism In Survivors', in The Journal Of British Cinema And Television (10:2), 321-39.

Hewett, Richard. (2014). 'Spaces Of Preparation: The Acton 'Hilton’ And Changing Patterns Of Television Drama Rehearsal', in The Historical Journal Of Film, Radio And Television (34.3), 331-344.

Jacobs, Jason. 2000. The Intimate Screen: Early British Television Drama, Oxford: Oxford University Press.

Klevan, Andrew. 2005. Film Performance: From Achievement to Appreciation, London: Wallflower Press. 
McNaughton, Douglas. 2014. “'Constipated, Studio-bound, Wall-confined, Rigid': The Influence Of British Actors' Equity On BBC Television Drama, 1948-72', in The British Journal Of Cinema And Television (11.1), 1-22.

Naremore, James. 1988. Acting in the Cinema, Berkeley: University of California Press. National Council for Drama Training (NCDT). 2002. Report Of The Recorded Media Working Party.

Pearson, Roberta. 1990. ““O’er Step Not The Modesty of Nature”: A Semiotic Approach To Acting In The Griffiths Biographs', in Zucker, Carole, ed. Making Visible The Invisible: An Anthology Of Original Essays On Film Acting, Metuchen, N.J.: Scarecrow Press.

Pudovkin, Vsevolod. 1953. 'Stanislavski’s System In The Cinema', Sight And Sound (22:3), $115-18,147-48$.

RADA. 1959. Prospectus 1959, London: RADA.

RADA. 1988. Prospectus 1988/89, London: RADA.

Rawlins, Trevor. 2010. 'Screen Acting And Performance Choices', Networking Knowledge: Journal of the MECCSA Postgraduate Network (3:2), 1-27.

Redgrave, Michael. 1970. ‘The Stanislavski Myth', originally published in New Theatre,(3:1), 1946, reprinted in Cole, Toby and Helen Krich Chinoy, eds. Actors On Acting: The Theories, Techniques And Practices Of The World's Great Actors, Told In Their Own Words, New York: Crown Publishers Inc., 403-8.

Sanderson, Michael. 1984. From Irving To Olivier: A Social History Of The Acting Profession In England 1880-1983, London: The Athlone Press. 
1 Although a comparison with other countries - in particular the US - would undoubtedly be of interest, the difficulties of providing a full historical overview again preclude this possibility. This article has its origins in a 2012 keynote given for the University of York's Playing The Small Screen symposium, and co-authored with Roberta Pearson. This compared the changing determinants of British and American television acting, rather than differences in performance style itself in these two countries. It is notable, however, that many of the industrial developments which affected the latter quite early on, such as the shift to single camera film work and reduction in rehearsal time, have subsequently taken a similar (if belated) course in the UK, which provides the sole focus of this article.

2 A possible exception here is the now largely defunct practice of weekly repertory theatre, which featured a similarly pressurised production schedule.

3 Recalling his 1980s work for the BBC, director Graeme Harper states that 'If you [were] doing a two-and-a-half-hour Shakespearean play you probably would have twelve weeks of rehearsal, certainly of preparation and rehearsal; it would be a massive rehearsal period.' Interviewed by the author, 22 January 2011.

4 This varied depending on the company. A BBC investigation found that 'some of the larger companies, such as Associated-Rediffusion and Granada, do have rehearsal rooms in their own buildings, but some of the smaller companies, such as Anglia, hire halls in the same way we do.' BBC WAC T16/16/2 - Memo from Legal Advisor, 13 February 1963.

5 The first director to work on a new series, the lead director will usually be involved in the casting of the regulars, in consultation with the casting director and executive producers. 
6 Howard Burch, interviewed by the author, 17 February 2011. All other Burch quotations are taken from this interview.

7 Radio's Val Gielgud had been jointly responsible for sound and vision prior to Barry becoming BBC Television's Head of Drama in 1952.

${ }^{8}$ The diminution in rehearsal was a gradual process, the roots of which can be traced to the decline in multi-camera studio production from the 1980s onwards. By the mid-1990s, the BBC's specially commissioned rehearsal rooms at Acton were falling into disuse (Hewett 2014).

9 Assistant Floor Manager.

10 Tony Garnett, interviewed by the author, 5 October 2010. All other Garnett quotations are taken from this interview.

11 Jonathan Powell, interviewed by the author, 2 February 2010.

12 The Broadcasting Act of 1990 obliged the Corporation to allocate 25 per cent of its output to independent companies, while Producer Choice was an internal policy under which producers could use outside suppliers as opposed to internal departments, should they prove more cost-effective. Few such independent suppliers shared the BBC's investment in the multi-camera system.

13 Jamie Payne, interviewed by the author, 12 April 2011. All other Payne quotations are taken from this interview.

14 Ibid. 
15 Andrew Gunn, interviewed by the author, 14 April 2011. All other Gunn quotations are taken from this interview.

16 The late Roger Lloyd Pack, interviewed by the author, 20 January 2011. All other Lloyd Pack quotations are taken from this interview.

17 This drama school had been established in 1950 by the Royal Scottish Academy of Music.

In 1968 these were combined as the Royal Scottish Academy of Music and Drama

(RSAMD), which was renamed the Royal Conservatoire of Scotland in 2011.

18 Julia Dalkin, who attended the academy in the early 1990s, recalls: 'We had about two, two-week courses of TV in the whole three years, because apparently they were just making more money renting it out.' Interviewed by the author, 7 November 2010.

19 Colin Teague, interviewed by the author, 29 March 2011.

20 Peter James, personal communication, 18 January 2011.

21 Kenneth Cope, interviewed by the author, 7 October 2011.

22 Louise Jameson, interviewed by the author, 2 April 2011. All other Jameson quotations are taken from this interview.

23 Patrick Malahide, interviewed by the author, 13 June 2011.

24 ITV employed casting departments at least as early as 1978 (Alvarado and Buscombe $1978,98)$.

25 Kevin McNally, interviewed by the author, 9 November 2010. 